Provided for non-commercial research and education use. Not for reproduction, distribution or commercial use.

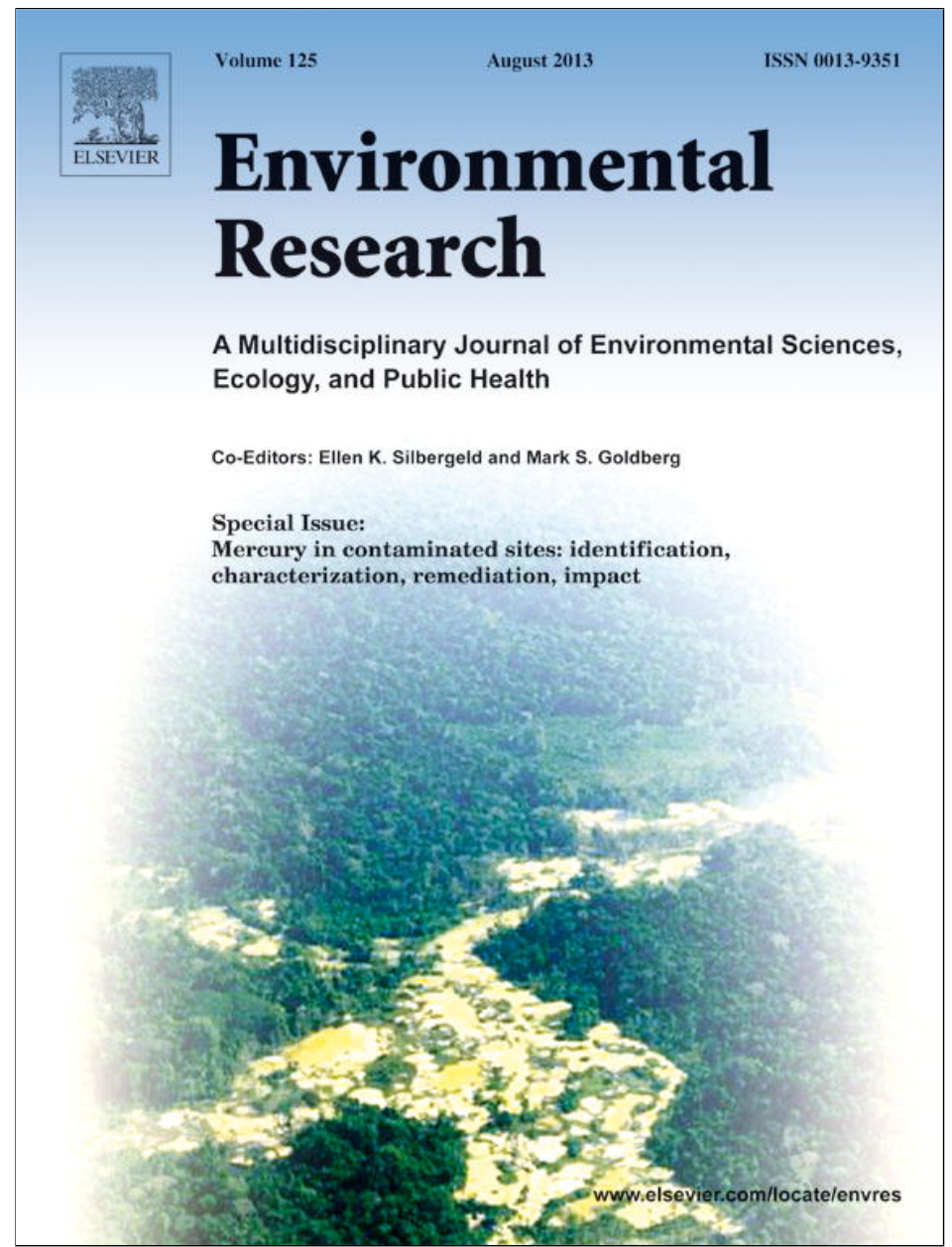

This article appeared in a journal published by Elsevier. The attached copy is furnished to the author for internal non-commercial research and education use, including for instruction at the authors institution and sharing with colleagues.

Other uses, including reproduction and distribution, or selling or licensing copies, or posting to personal, institutional or third party websites are prohibited.

In most cases authors are permitted to post their version of the article (e.g. in Word or Tex form) to their personal website or institutional repository. Authors requiring further information regarding Elsevier's archiving and manuscript policies are encouraged to visit:

http://www.elsevier.com/authorsrights 


\title{
Industrial and natural sources of gaseous elemental mercury in the Almadén district (Spain): An updated report on this issue after the ceasing of mining and metallurgical activities in 2003 and major land reclamation works
}

\author{
Pablo Higueras ${ }^{\mathrm{a}, \mathrm{b}, *}$, José María Esbrí ${ }^{\mathrm{a}, \mathrm{b}}$, Roberto Oyarzun ${ }^{\mathrm{b}, \mathrm{c}}$, Willans Llanos ${ }^{\mathrm{b}, \mathrm{c}}$, \\ Alba Martínez-Coronado ${ }^{\mathrm{b}}$, Javier Lillo ${ }^{\mathrm{b}, \mathrm{d}}$, Miguel Angel López-Berdonces ${ }^{\mathrm{b}}$, Eva Maria \\ García-Noguero ${ }^{\mathrm{b}}$ \\ a Departamento de Ingeniería Geológica y Minera, Escuela Universitaria Politécnica de Almadén, Universidad de Castilla-La Mancha, Plaza M. Meca 1, \\ 13400 Almadén, Spain \\ ${ }^{\mathrm{b}}$ Instituto de Geología Aplicada (IGeA), Universidad de Castilla-La Mancha, Plaza M. Meca 1, 13400 Almadén, Spain

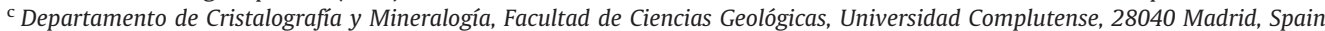 \\ ${ }^{\mathrm{d}}$ Escuela Superior de Ciencias Experimentales y Tecnología, Universidad Rey Juan Carlos, Tulipán s/n, 28933 Móstoles (Madrid), Spain
}

\section{A R T I C L E I N F O}

Available online 7 March 2013

\section{Keywords:}

Almadén district

Spain

Gaseous elemental mercury

Emissions

Restoration works

\begin{abstract}
A B S T R A C T
Two events during the last decade had major environmental repercussions in Almadén town (Spain). First it was the ceasing of activities in the mercury mine and metallurgical facilities in 2003, and then the finalization of the restoration works on the main waste dump in 2008. The combination of both events brought about a dramatic drop in the emissions of gaseous elemental mercury (GEM) to the atmosphere. Although no one would now call the Almadén area as 'mercury-free', the GEM levels have fallen beneath international reference safety levels for the first time in centuries. This has been a major breakthrough because in less than one decade the site went from GEM levels in the order of "tens of thousands" to mere "tens" nanogram per cubic meter. Although these figures are per se a remarkable achievement, they do not mark the end of the environmental concerns in the Almadén district. Two other sites remain as potential environmental hazards. (1) The Las Cuevas mercury storage complex, a partially restored ex-mining site where liquid mercury is being stored. The MERSADE Project (LIFEEuropean Union) has tested the Las Cuevas complex as a potential site for the installation of a future European prototype safe deposit of surplus mercury from industrial activities. Despite restoration works carried out in 2004, the Las Cuevas complex can still be regarded as hotspot of mercury contamination, with high concentrations above $800 \mu \mathrm{g} \mathrm{g}^{-1} \mathrm{Hg}_{\text {soil }}$ and $300 \mathrm{ng} \mathrm{m}^{-3} \mathrm{Hg}_{\text {gas }}$. However, as predicted by air contamination modeling using the ISC-AERMOD software, GEM concentrations fade away in a short distance following the formation of a NW-SE oriented narrow plume extending for a few hundred meters from the complex perimeter. (2) Far more dangerous from the human health perspective is the Almadenejos area, hosting the small Almadenejos village, the so-called Cerco de Almadenejos (CDA; an old metallurgical precinct), and the mines of La Nueva Concepción, La Vieja Concepción and El Entredicho. The CDA is an old metallurgical site that operated between 1794 and 1861 , leaving behind a legacy of extremely contaminated soils (mean concentration $=4220 \mu \mathrm{g} \mathrm{g}^{-1} \mathrm{Hg}$ ) and GEM emissions that in summer can reach levels up to 4,000-5,000 $\mathrm{ng} \mathrm{m}^{-3}$. Thus the CDA remains the sole 'urban' site in the district surpassing GEM international reference safety levels. In order to prevent these emissions, the CDA requires immediate action regarding restoration works. These could involve the full removal of soils or their permanent capping to create an impermeable barrier.
\end{abstract}

(c) 2012 Elsevier Inc. All rights reserved.
* Corresponding author at: Departamento de Ingeniería Geológica y Minera, Escuela Universitaria Politécnica de Almadén, Universidad de Castilla-La Mancha, Plaza M. Meca 1, 13400 Almadén, Spain. Fax: +34 926295301.

E-mail address: pablo.higueras@uclm.es (P. Higueras).

\section{Introduction}

The Almadén district (Spain) was by far the largest miningmetallurgical operation in the world. The district is located in central Spain (Fig. 1A), and it mined and refined one-third of the total world production of this chemical element. The district includes a series of mercury ore deposits having in common a very simple mineral 


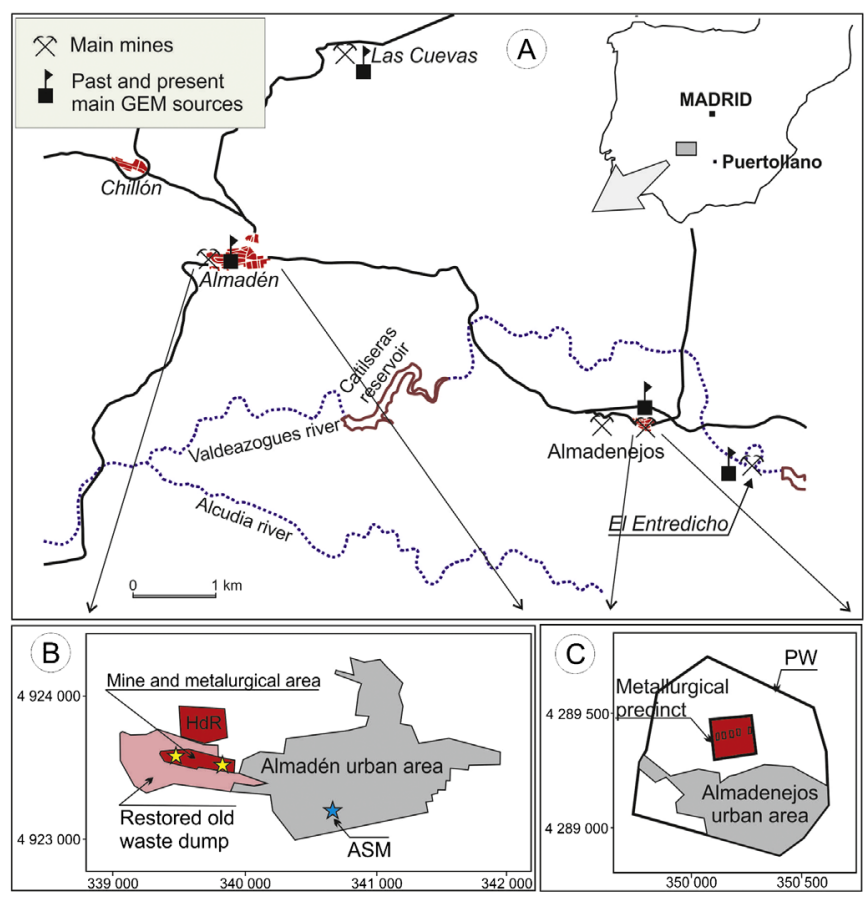

Fig. 1. Sketch maps of location of Almadén district area, including the locations of the different studied sites (A), and details of Almadén (B) and Almadenejos (C) surroundings. HdR: Huerta del Rey metallurgical precinct; ASM: Almadén School of Mines; OW: Almadenejos outer wall.

paragenesis, including dominant cinnabar $(\mathrm{HgS})$ and minor pyrite $\left(\mathrm{FeS}_{2}\right)$. The mercury ore was extracted from several mines (underground and open pit operations), including the world-famous giant Almadén mine, El Entredicho, Nueva Concepción, Vieja Concepción, and Las Cuevas (apart from much smaller operations of lesser importance). Centuries of mining and metallurgical operations left a contamination legacy that only in recent years has come to be fully understood. In this regard, mercury is not just 'another heavy metal' as it has the consideration of a 'global pollutant' because of its ability to undergo long distance transport into the atmosphere. The main concern for this easy dispersion comes due to the physical property of most $\mathrm{Hg}$ species to volatilize to gaseous elemental mercury (GEM), with an estimated residence time in the atmosphere of about one year (Slemr, 1996). However, recent data on mass balance from mineralized source areas suggest that this residence time may be much shorter, in the order of hours to weeks (Gustin et al., 2008).

The relatively homogeneous mercury content in the atmosphere should be the result of a continuous short-term exchange between soil, vegetation and air, making it suitable for oxidation and dryand wet-deposition (Gustin et al., 2008). In this regard, in response to concerns based on the potential dangers posed by this element, the authorities (at different organizational levels) have been doing whatever is legally possible to reduce human emissions to the atmosphere (Lee \& Lee, 2012). For example, in January 2005 the European Commission adopted a mercury strategy (EURLex, 2005) with the aim of phasing out this toxic metal. The strategy stated that surplus mercury should be safely stored or disposed of. As early as in 1992 the European Union (EU) launched LIFE (the Financial Instrument for the Environment). LIFE contributed to the implementation, development and enhancement of environmental policies and legislations as well as the integration of the environment into the other EU policies. The third 2006 LIFE-Environment preparatory project was MERSADE (an acronym for mercury safe deposit), involving the design, construction and validation of a prototype installation for a safe deposit of surplus mercury from European industry (LIFE06 PREP/E/000003) (European Union, 2006).
Mercury mining sites are not usually considered as important sources of GEM emission, and published quantitative approaches (Pacyna and Munch, 1991; Pacyna and Pacyna, 2002; Pacyna et al., 2006; 2010; Pirrone et al., 2010; among others) point to other sources such as coal combustion as being far more important (Billings and Matson, 1972), particularly when pyrite-rich coal is burned. On the other hand, contributions of the most important $\mathrm{Hg}$ miningmetallurgical sites to this global GEM pool cannot be denied as significant (Kocman and Horvat, 2011), and deserve attention and efforts to reduce its importance, in particular now that most of them have closed. In this regard, GEM concentrations in Almadén have been locally studied by Ferrara et al. (1998), Higueras et al. (2006), Llanos et al. (2010) and Martínez-Coronado et al. (2011). Besides, Llanos et al. (2011) described, modeled and quantified emissions from local contaminated sites. In this work we go a step further, presenting regional (district-wide) data for GEM. We also describe and discuss the important reduction in mercury emissions after the mine and metallurgical complex of Almadén town ceased activities in June 2003, and the subsequent restoration of the main metallurgical waste dump that was completed in 2008.

\section{The context: main emission sources}

\subsection{The Almadén complex}

The Almadén district includes a number of mines, in particular the large Almadén mine and metallurgical complex that roasted the mercury ore. The Almadén complex was doubtless the main source for atmospheric mercury dispersion in the area, and is located immediately to the west of Almadén town (urban area: 6100 inhabitants in 2011). The complex (Fig. 1B) comprises the mine (now an excellent educational theme park for visitors), the metallurgical precincts of Cerco de San Teodoro and Huerta del Rey, and the now restored metallurgical waste dump. Although the mine was exploited since Roman times, it was not until the 16 th century that its modern underground configuration began to take place. No wonder, Almadén was a major strategic asset for the Spanish Crown as it provided the mercury needed for the recovery of gold and silver from the mines of the American colonies. Total production from this mine can be estimated to be $8.5 \times 10^{6} \mathrm{t}$, representing about $90 \%$ of the total production of the district. The metallurgical precinct of Huerta del Rey was active from remote times to an undetermined moment of the 17 th century, when a fire in the old mine (the so-called North Branch) favoured the discovery of the South Branch. By then, the works centered on the new Cerco de San Teodoro precinct, an area surrounded by a $3 \mathrm{~m}$ high stone wall, and located adjacent to the urban area. The Huerta del Rey precinct included a calcines (the cinnabar roasting residue) dump, today almost completely dismantled because the wastes were used for road construction and repairs, and therefore dispersed throughout the region. Besides, the Cerco de San Teodoro (CST) mostly hosted calcines because the barren rock was reintroduced to the mine to sustain the chosen cut and fill mining system. The CST covered an area about $250,000 \mathrm{~m}^{2}$, was about $60 \mathrm{~m}$ high, and had sub-economic grades of $0.1-0.2 \% \mathrm{Hg}$ (a major environmental hazard). The dump was restored between 2006 and 2008, and the works comprised morphological remodeling and the sealing of residues to avoid mercury leaks to surface waters and the atmosphere. The sealing was achieved by covering of the wastes with a geotextile and this surface with some $50 \mathrm{~cm}$ of soil with prairie-based vegetation. The margins of the dump were encircled with a drainage channel aimed to collect leachates from the calcines. No basal sealing was done because the rock beneath was considered to be of very low permeability. In this regard, the rock may be, but fractures (and 
all rocks are fractured) create permeability whether the rock is intrinsically permeable or not.

The metallurgical practices at Almadén varied considerably through time, from very primitives furnaces made of brick and pottery (Bustamante furnaces), to the Pacific furnaces, active from 1950 to 2003. Every change in furnace type resulted in important increases in effectiveness (Esbrí et al., 2010) and reductions in mercury emissions, but usually also implied a rise in production capacity, favouring the rise in absolute terms of these emissions.

\subsection{The Almadenejos mining and metallurgical complex}

The Almadenejos metallurgical-mining site is located about $12 \mathrm{~km}$ away to the ESE of Almadén (Fig. 1A), and includes three mines and a metallurgical precinct that was active from 1795 to 1864. The metallurgical site (known as the Cerco de Almadenejos: CDA) (Fig. 1C) can be fully regarded as an environmental disaster area, with a mean mercury concentration in soils of $4220 \mu \mathrm{g} \mathrm{g}^{-1}$ (Martínez-Coronado et al., 2011). The mines are those of La Vieja Concepción (1699-1800), La Nueva Concepción (1795-1860) and El Entredicho (1983-1997). The first two are located close to the small village of Almadenejos (502 inhabitants in 2011), and the ore was treated at the CDA (Martínez-Coronado et al., 2011). Both were underground mines, with waste dumps of minor dimensions. Environmental research currently being undertaken at the Nueva Concepción shows low GEM levels ( $<50 \mathrm{ng} \mathrm{m}^{-3}$; winter survey) although the soils are more contaminated (up to $720 \mu \mathrm{g} \mathrm{g}^{-1}$ ) (Castillo Cuacés, 2012; Herrera Jimenez, 2012), whereas at La Vieja Concepción the waste dump has gone missing completely. On the other hand, the El Entredicho mining site is located $3 \mathrm{~km}$ to the ESE of Almadenejos (Fig. 1A). The mine underwent minor activity during Roman and Arab times, and modern open pit mining took place between 1983 and 1997. The site had two waste dumps that were restored in 1999 and 20032004; the waste dumps were covered with soil and revegetated.

The CDA (Martínez-Coronado et al., 2011) is located immediately to the north of the village, has an area of about $36,000 \mathrm{~m}^{2}$ and is completely surrounded by a deteriorated stone wall (Fig. 1C; see also Figs. 1 and 2, Martínez-Coronado et al., 2011). It is not clear whether this wall was built to prevent robbery of mercury metal or to impede prisoners from escaping: forced labor operations were common in those old days. The metallurgical precinct originally had six red-brick furnaces (Bustamante type) for cinnabar roasting, which are currently in ruinous conditions and one has gone missing entirely. At present the precinct is used by the locals to raise pigs and other livestock. From the viewpoint of $\mathrm{Hg}$ pollution, the CDA can be regarded as one of the most contaminated sites in the whole Almadén district. Hundreds of years of primitive $\mathrm{Hg}$ metallurgical practices left a toxic legacy of highly contaminated soils. The environmental hazards induced by such contamination do not end at the walls of the CDA, because high concentrations of $\mathrm{Hg}_{\text {soil }}$ and GEM are persistent and extend well beyond the precinct. Gray et al. (2010) proved the high toxicity of these residua.

\subsection{The Las Cuevas complex}

The Las Cuevas mine (Llanos et al., 2010) is located some $9 \mathrm{~km}$ to the NE of Almadén (Fig. 1A) and was operated during the 1980s and 1990s. A ground collapse in 1997 induced the formation of a large sinkhole on the surface, which resulted in downward infiltration of materials from a debris dump left from the days of mine preparation works. With the mine closure and cessation of the activity in February 2000, a plan for permanent abandonment and environmental restoration of affected land was presented. At the end of that year, the works started with the
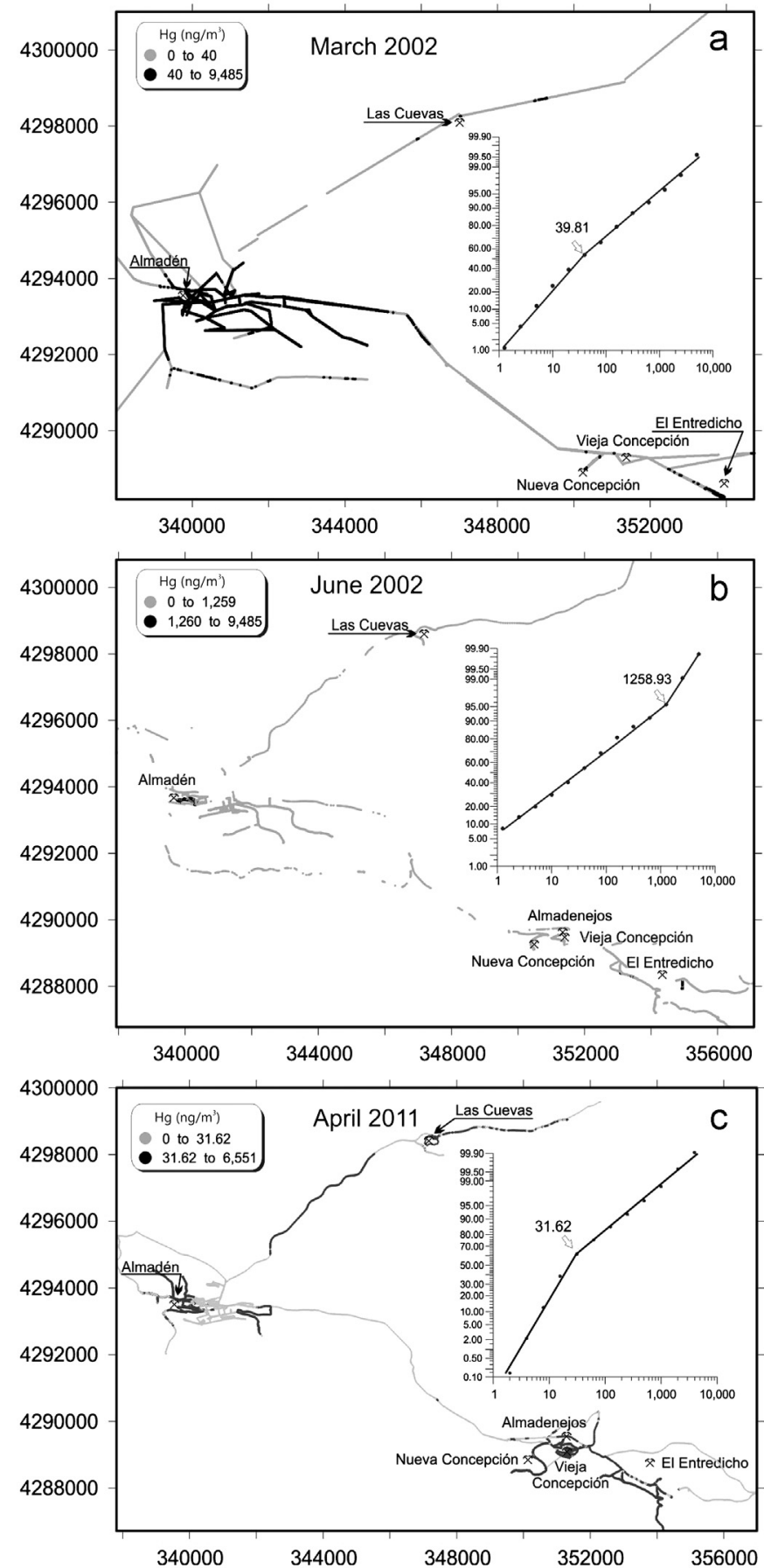

Fig. 2. Sketch maps of GEM distribution after the March 2002 (A), June 2002 (B) and April 2011 (C) regional surveys. Enclosed in the corresponding figure we include the Lepeltier graphics showing the breaking points separating background and anomalous populations and indicating the thresholds used in the mapping.

regeneration of the area that had been occupied by the debris dump, the area affected by the ground collapse, and eventually in 2003 on abandoned waste rock dumps. In January 2005 the European Commission adopted a mercury strategy with the aim of phasing out this toxic metal (EUR-Lex, 2005). The strategy stated that surplus mercury should be safely stored or disposed of. As early as in 1992 the European Union (EU) launched LIFE (the Financial Instrument for the Environment). LIFE contributes to the implementation, development and enhancement of environmental policies and legislations as well as the integration of the environment into other EU policies. LIFE also supports the 
development of new solutions to environmental problems facing the EU. The third 2006 LIFE-Environment preparatory project was MERSADE (an acronym for mercury safe deposit), which involved the design, construction and validation of a prototype installation for a safe deposit of surplus mercury from European industry (LIFE06 PREP/E/000003) (European Union, 2006). From a pragmatic point of view, if a safe deposit of liquid mercury had to be built within the EU, it seemed only logical to choose the Almadén district (Spain) as the most adequate site: decades if not centuries of expertise on mercury and abandoned mining complexes could be reutilized for different purposes. The complex of Las Cuevas was chosen as the most suitable site to base the MERSADE project because the site was already being subjected to land reclamation works, it is near and well connected to the main Spanish road network, and last but not least, different from the Almadén or the Almadenejos complexes, the Las Cuevas complex is far away from populated areas.

In 2004 a stock of mercury was transferred to Las Cuevas from the Almadén mining complex. To do so the old vehicle maintenance hangar was transformed into a warehouse for the handling of mercury flasks ( $34.5 \mathrm{~kg} \mathrm{Hg}$ ) and large mercury vessels $(1000 \mathrm{~kg})$. A safety container (in case of accidental spills) was built and six stainless steel storage tanks for liquid mercury were installed on top of it. Each tank can hold up to 30,000 l (414t) of mercury. No emissions of mercury from the tanks were detected. However, the handling of flasks and vessels at the old vehicle maintenance hangar resulted in discrete incidents leading to the accidental loss of liquid mercury (Llanos et al., 2010). Given that liquid mercury is a highly persistent pollutant, difficult to eradicate from contaminated surfaces, this site is a net source of gaseous mercury, which may mask signals from the safe storage.

Mercury concentrations in soils and air (Llanos et al., 2010) are remarkably above baselines from background areas, although the results are well within the ranges for the Almaden district. As expected the highs of mercury concentration in soils (above $800 \mu \mathrm{g} \mathrm{g}^{-1}$ ) and air (above $300 \mathrm{ng} \mathrm{m}^{-3}$ ) are located inside the Las Cuevas complex perimeter. These are related to the previous sites of mineral stockpiling, waste-rock emplacement, and present activities involving handling of mercury vessels near the main building of the complex. However, concentration in soils above $30 \mu \mathrm{g} \mathrm{g}^{-1} \mathrm{Hg}$, that is, about three orders of magnitude above world baseline figures, extend well beyond the complex for distances greater than $2 \mathrm{~km}$. Similar results were obtained for mercury in air, although the anomaly rapidly fades away beyond a few hundred meters.

\subsection{Other areas}

Besides these main sites, an undetermined number of minor sources are scattered throughout the district. They include tracks where mine residues were used during construction works, small mine prospects (some of them with small mineral dumps), as well as other sectors distributed in the region that served as transient metallurgical sites due to the lack of wood (to fire the furnaces) in the proximities of Almadén during extremely active periods.

\section{Materials and methods}

The surveys to assess GEM concentration in the region and local areas were carried out using several LUMEX RA-915+ and RA-915M portable analyzers for continuous Hg measurements and a TEKRAN 2537B device for fixed measurements. The LUMEX devices analytical procedure is based on Zeeman Atomic Absorption Spectrometry with High Frequency Modulation of light polarization (ZAAS-HFM) (Sholupov et al., 2004). Application of Zeeman background correction and a multipath analytical cell provides high selectivity and sensitivity of measurements The instrument allows determination of $\mathrm{Hg}$ in air directly with an ultra low detection limit in real time. This detection limit is governed by shot noise and equals $\mathrm{CaDL}=2 \mathrm{ng} \mathrm{m}^{-3}$ (average measuring time $=5 \mathrm{~s}$ ) and $\mathrm{CaDL}=0.3 \mathrm{ng} \mathrm{m}^{-3}$ (average measuring time $=30 \mathrm{~s}$ ) for mercury determination in air. The dynamic range covers four orders of magnitude $\left(2-25,000 \mathrm{ng} \mathrm{m}^{-3}\right)$. The real time measurements are carried out by visualization of the process on a digital display. Online data recording is done by connecting the instrument to a laptop computer. The whole process is completed in the field with geographic location of single data using a GPS. The simplest procedure in the survey involved preliminary geographic data acquisition (GPS Garmin e-map) at singular points such as crossroads or bridges, whereas the advanced procedure involved continuous measurements using a modern GPS connected to the laptop computer that controls the $\mathrm{Hg}$ analyzer. The final output is a file containing both geographic position and mercury values. The statistical treatment of data was carried out using MINITAB 15.0, whereas the spatial distribution was plotted via SURFER 9.0. The LUMEX-based measurement surveys were carried out in three different ways: (1) express surveys, performed using a car, with GPS control of every analysis position. The area to cover was planned previously and the survey used all local roads and tracks to cover the whole area with discrete sections, with the final aim of collecting data not only from the mercury source but also from background areas surrounding the anomaly completely; (2) area network surveys, consisting of measurements in a predetermined array of sites close to one of the described source areas, repeated at variable time intervals; and (3) fixed point surveys, where the device was located in a point of interest for a predetermined time span, recording secular variations.

The TEKRAN 2537B is an automated ambient air analyzer that performs continuous long-term, unattended analysis of gaseous elemental mercury, and the 2537B instrument is most often used with the models 1130 and 1135 to continuously measure atmospheric mercury speciation (Tekran, 2012). Total flow through the 1130 and 1135 systems was 8.75 Standard liters per minute (SLPM), whereas the flow was 1.25 SLPM for the 2537B system. GEM was collected within the 2537B device using gold cartridges for 15 min intervals, while RGM and PM were collected over 1:30 h intervals on a $\mathrm{KCl}$-coated denuder and regenerable filter assembly respectively. These operationally defined forms of $\mathrm{Hg}$ were sequentially thermally desorbed and quantified using the Cold Vapor Atomic Fluorescence Spectrometer (CV-AFS) instrument located in the TEKRAN 2537B. Variability of Tekran measured concentrations between co-located instruments has been reported to be in the order of $10 \%$ for GEM and $10-30 \%$ for RGM and PM respectively (e.g., Abbott et al., 2008; Landis and Keeler, 2002; Lyman and Gustin, 2008; Peterson and Gustin, 2008). The manufacturer detection limit for the TEKRAN 2537B is $<0.1 \mathrm{ng} \mathrm{Hg} \mathrm{m}^{-3}$ (Tekran, 2012), whereas that calculated for reactive gaseous mercury (RGM) and particulate mercury (PM) (three times the standard deviation of the blank) was $3 \mathrm{pg} \mathrm{m}^{-3}$, similar to that reported by others (e.g., Poissant et al., 2005; Hall et al., 2006). The CV-AFS was calibrated every 3 days using an internal permeation source. The gold cartridges were replaced when injection recoveries fell below 95\%. The RGM denuders and PM regenerable particulate filter were replaced every month. An intercomparison exercise with LUMEX RA-915M and TEKRAN 2537B was done in collaboration with the Spanish "Instituto de Salud Carlos III". The results yielded a compatibility index (after ISO/IEC Guide 43-1, 1997) below 1 during all the experiments (Fernández-Patier and Ramos-Díaz, 2011). Annual and seasonal mean Hg species were calculated using daily mean values. Data was managed and analyzed using MICROSOFT OFFICE EXCEL 2011 and MINITAB 15.

We present data from regional surveys carried out with LUMEX RA-915 devices in 2002 and 2011, so before and after the cessation of the metallurgical activity; from local surveys carried out in Almadén mining complex before, during and after the main waste dump restoration; from network based surveys centered in Almadén, Almadenejos and Las Cuevas during the period 2007-2011; and also from a survey carried out at Las Cuevas using the TEKRAN 2537B analyzer. Meteorological data was collected using three automatic stations (DAVIS Vantage Pro2) located at Las Cuevas, Almadenejos and Almadén during the period 20072012. This fully automatic equipment registers data of temperature, humidity, wind velocity, wind direction, solar radiation, UV radiation and soil temperature and moisture at two different depths (10 and $40 \mathrm{~cm}$ ).

Regarding the statistical analysis of data we followed this principle: when dealing with a large amount of geochemical data, the first step is to find the distribution pattern that best fits the various sets of observations. In most cases, the lognormal distribution pattern (e.g., Lepeltier, 1969; Limpert et al., 2001) appeared to be the one most applicable to the results. A lognormal distribution curve (Lepeltier, 1969) is defined by two parameters: one dependent on the mean value, and the other dependent on the character of value-distribution. The two parameters can be determined graphically by means of cumulative frequency curves in log-probability plots.

\section{Results and discussion}

\subsection{The regional surveys: from 2002 to 2011}

We report data from three regional surveys, two carried out in 2002, and one in 2011. We conducted the first two in March and June 2002 , the first one with temperatures of $10-15^{\circ} \mathrm{C}$, and mostly 
clouded skies, and the second one with temperatures of $22-35^{\circ} \mathrm{C}$, and clear skies. Given the particular characteristics of the study area, which at the time comprised several potential sources of mercury emission to the atmosphere (the Almadén metallurgical plant, mines, prospects, mineral dumps, abandoned metallurgical sites) the data were treated both as a single global population and as separate ones. The data have a log-normal distribution, with a multimode behavior. Taking this into account, we decided to investigate the data sets using the Lepeltier (1969) method, because it is an ideal procedure to deal with complex populations. Its graphical approach, based on $\log \mathrm{x}$ versus cumulative probability, nicely separates normal from transitional and anomalous populations. Given that the $Y$ axis represents cumulative Gaussian distributions, each straight curve is representative of an individual data subset having a log-normal distribution. The changes in slope (breaks) mark the boundaries between populations (see Fig. 2). Additionally, the Gaussian or normal distribution is assumed to describe the random variation that occurs in a data set. However, many distributions show important skewness, which disappears if we deal with the logarithm of the values $(\log \mathrm{x})$. If this is the case, we say that $\log \mathrm{x}$ has a normal distribution, or simpler, that the distribution is log-normal (e.g., Limpert et al., 2001). In this regard, the geometric mean is often a useful summary for highly skewed data. Different from the arithmetic mean, the geometric mean is a measure of central tendency, just like a median. Thus, we have expressed our mean results as both, arithmetic and geometric means. For simplicity we use the term "mean" instead of "arithmetic mean", whereas the antilog of the arithmetic mean of the logarithmic values will be kept as "geometric mean". Apart from statistical considerations, another issue to be considered here are the relationships between GEM emission, light, and temperature; photoreduction generates an initial pool of $\mathrm{Hg}^{0}$ that is later released from the soil (as GEM) when temperatures and convective transfer increase during the day (Gustin et al., 2002). This results in a seasonal variation in mercury emissions, with an increase of the release of gaseous mercury as the days become brighter and warmer.

The first survey was carried out in March 2002 and showed a mean GEM concentration of $213.7 \mathrm{ng} \mathrm{m}^{-3}$ (geometric mean= $38.8 \mathrm{ng} \mathrm{m}^{-3}$ ), whereas the June survey had a slightly lower mean value of $195.7 \mathrm{ng} \mathrm{m}^{-3}$ (geometric mean $=29.1 \mathrm{ng} \mathrm{m}^{-3}$ ) (Table 1 ). The strong difference between the arithmetic and geometric means reflects the highly skewed character of both data sets (a vast majority of low values), and in this regard, the lower geometric mean may be more properly reflecting the actual mean concentrations. However, even the geometric means for the Almadén district can be regarded as 'anomalous' compared to the

Table 1

Summary of data from the regional surveys, carried out in March 2002, June 2002 and April 2011. N: number of determinations; GM: geometric mean; Max: maximum concentration registered. All data are in nanograms per cubic meter $\left(\mathrm{ng} \mathrm{m}^{-3}\right)$.

\begin{tabular}{lrcrrr}
\hline Area and date & \multicolumn{1}{c}{ Mean } & SD & GM & Max \\
\hline District wide, March 2002 & 15337 & 213.9 & 644.9 & 38.8 & 9485 \\
District wide, June 2002 & 3760 & 195.7 & 514.2 & 29.1 & 6892 \\
District wide, April 2011 & 16032 & 934 & 272.8 & 28.6 & 6551 \\
Almadén, March 2002 & 9037 & 352.7 & 811.5 & 107.6 & 9485 \\
Almadén, June 2002 & 1575 & 270.6 & 628.2 & 49.6 & 6892 \\
Almadén, April 2011 & 5979 & 33.3 & 44.9 & 22.5 & 916 \\
Las Cuevas, March 2002 & 175 & 7.5 & 7.7 & 5.0 & 51 \\
Las Cuevas, June 2002 & 142 & 23.9 & 34.3 & 10.9 & 234 \\
Las Cuevas, April 2011 & 1483 & 337.5 & 610.7 & 84.2 & 4429 \\
Almadenejos, March 2002 & 1617 & 11.6 & 10.1 & 9.0 & 126 \\
Almadenejos, June 2002 & 355 & 26.1 & 31.2 & 12.0 & 188 \\
Almadenejos, April 2011 & 3756 & 29.1 & 89.6 & 13.8 & 2228 \\
El Entredicho, March 2002 & 932 & 27.7 & 45.5 & 18.0 & 605 \\
El Entredicho, June 2002 & 984 & 291.3 & 567.6 & 68.0 & 3111 \\
El Entredicho, April 2011 & 3582 & 181.1 & 349.1 & 82.2 & 6551 \\
\hline
\end{tabular}

$\sim 2-3 \mathrm{ng} \mathrm{m}^{-3}$ reported for background areas (Wängberg et al., 2001 ) or the $\sim 2-4 \mathrm{ng} \mathrm{m}^{-3}$ measured by us in Puertollano, $70 \mathrm{~km}$ to the west of Almadén town. On the other hand, the apparently odd result for June (lower concentration despite brighter and warmer days) can be explained in terms of the inactivity of the Almadén metallurgy, which at the time of the survey was shut down for several days. Thus, a first approach toward the identification of the sources of atmospheric mercury in the Almadén district leads to the metallurgical and mining complex of Almadén town, where Ferrara et al. (1998) measured up to $20,000 \mathrm{ng} \mathrm{m}^{-3}$. The main emission identified sites were the metallurgical plant, the underground mine ventilation system (in underground mines air is pumped in and out), the waste dumps, and droplets of native mercury covering the ground in the complex. However, given the size of the Almadén district we also expected other sources to contribute to the total budget of atmospheric mercury. Since the concentration in the substrate is the dominant factor controlling the emission of mercury (Gustin et al., 2000), a naturally enriched realm is bound to be an important source of atmospheric mercury. Considering that an enriched substrate is one containing $>0.1 \mu \mathrm{gg}^{-1} \mathrm{Hg}$ (Gustin et al., 2000), we may regard the Almadén district as extremely enriched (6-8889 $\mu \mathrm{g} \mathrm{g}^{-1} \mathrm{Hg}$ in soils) (Higueras et al., 2003). In this respect, at the time we were able to clearly differentiate four sectors in the district displaying much higher than normal values of GEM (in decreasing order of importance): (1) Almadén (main underground mine and metallurgical facilities); (2) Almadenejos (abandoned metallurgical site); (3) El Entredicho (inactive open pit mine and waste dumps); and (4) Las Cuevas (inactive underground mine and mineral dumps).

The Almadén anomaly (town and its surroundings), with mean values of $352.7 \mathrm{ng} \mathrm{g}^{-3}$ (March) (geometric mean=107.6) and $270.6 \mathrm{ng} \mathrm{m}^{-3}$ (June) (geometric mean $=49.6$ ) (Table 1), is strongly controlled by the emissions from the roaster. For example, a static continuous measurement (67 min, on June 26th 2002, between 11:00 a.m. and 12:07 p.m.) at the entrance of the metallurgical site (250 $\mathrm{m}$ away from the chimney) showed an extremely high mean value of $14,236 \mathrm{ng} \mathrm{m}^{-3}(\mathrm{SD}=5326)$. Statistical analysis allows a closer inspection of the Almadén seasonal variation of data (districtwide survey). Besides, we observe an anomalous population in March 2002 starting at $40 \mathrm{ng} \mathrm{m}^{-3}$ (Fig. 2A), whereas in the June 2002 data the break starts at $1259 \mathrm{ng} \mathrm{m}^{-3}$ (Fig. 2B). Thus, from this improved (Lepeltier based) statistical perspective, the results show that the brighter days and much higher temperatures during the June 2002 survey $\left(22-35^{\circ} \mathrm{C}\right.$ versus $10-15^{\circ} \mathrm{C}$ in March 2002) resulted in anomalous populations forming at higher values.

Almadenejos, Las Cuevas, and El Entredicho may represent endmembers of a complex environmental scenario. The GEM source at Almadenejos is provided by the highly contaminated soils, whereas El Entredicho and Las Cuevas are inactive mines. However, while Las Cuevas is an underground mine, El Entredicho is a large open pit operation. The maxima concentrations measured in these sites are particularly significant: 3111 and $234 \mathrm{ng} \mathrm{m}^{-3}$ for El Entredicho and Las Cuevas respectively (Table 1), which suggests that the open pit operation may have represented a much more important environmental concern than the underground mine. The June survey showed a much more complex statistical scenario. Thus, while in March 2002 data set for Almadenejos we observe two populations (a single break) (Fig. 3D), in June 2002 it appears to be a transitional one (Fig. 3E). At Las Cuevas the anomalous March 2002 population starts at $14 \mathrm{ng} \mathrm{m}^{-3}$ (Fig. 4D) whereas in June 2002 we detect a transitional one at $>28 \mathrm{ng} \mathrm{m}^{-3}$ and then an anomalous one at $>79 \mathrm{ng} \mathrm{m}^{-3}$ (Fig. 4E). This case is particularly significant at El Entredicho: the March data show a single break at $20 \mathrm{ng} \mathrm{m}^{-3}$ (Fig. 4A), whereas the June survey showed breaks at $224 \mathrm{ng} \mathrm{m}^{-3}$ (transitional population) and $1259 \mathrm{ng} \mathrm{m}^{-3}$ (Fig. 4B). We interpret these results in terms of increasingly complex environmental conditions as the mostly cold 

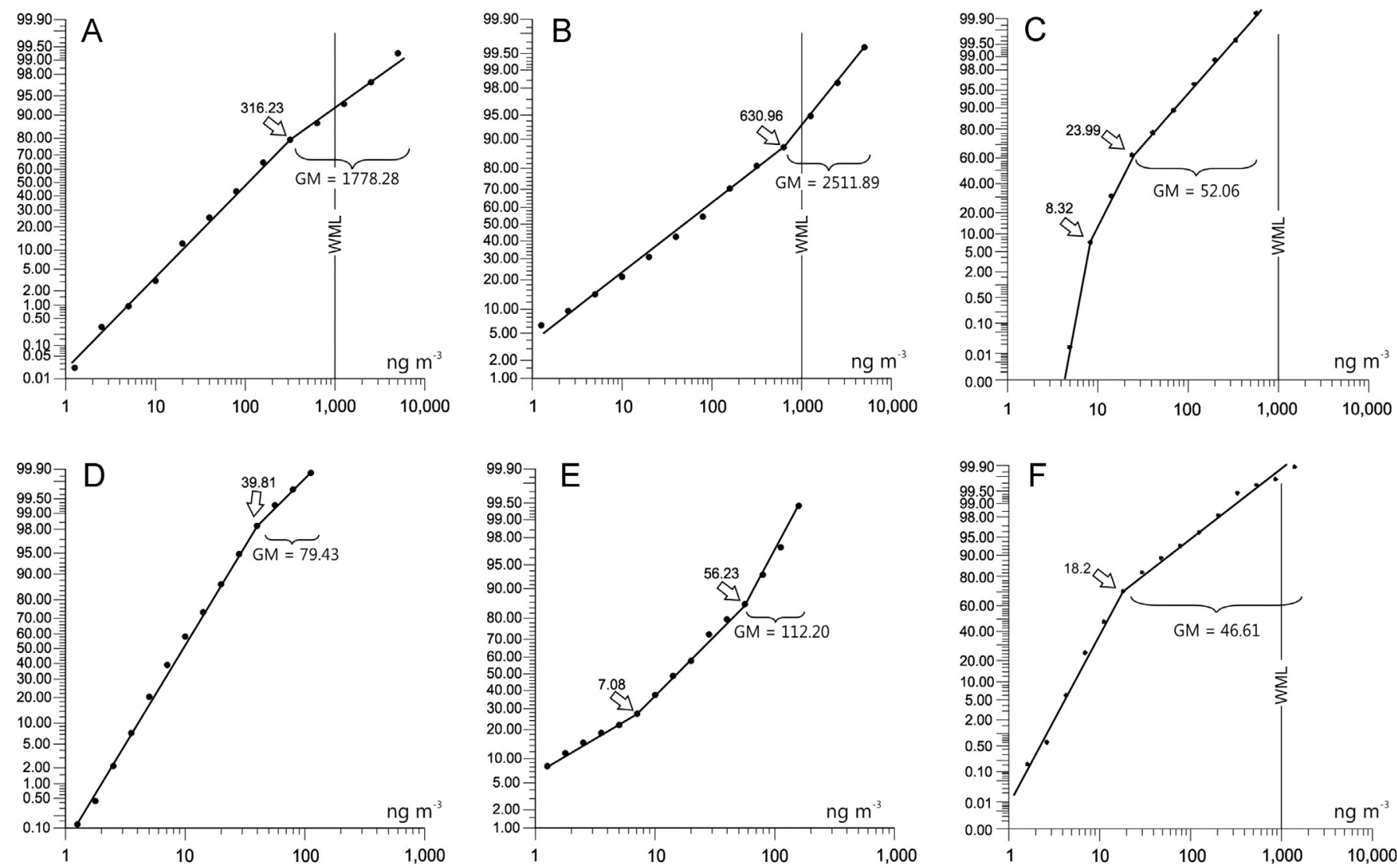

Fig. 3. Lepeltier graphics depicting distribution of normal and anomalous populations at (A-C) Almadén, town and surroundings (main underground mine, metallurgical plant), during March 2002, June 2002 and April 2011; and (D-F) the Almadenejos ruins of the old metallurgical site during March 2002 , June 2002 and April 2011. GM: geometric mean of the corresponding anomalous populations. WML: WHO (2000) maximum level.

and darker scenario of winter grades into the brighter and warmer days of spring. Thus, while winter days are rather homogeneous, spring brings variable conditions in central Spain (it is said that in a single day one may observe the four seasons). In this regard, this extreme and sometimes puzzling meteorological variability results in more complex statistical scenarios, beyond the typical bimodal behavior (background-anomalous $\rightarrow$ background-transitional-anomalous), thus involving formation of a third, transitional data population.

Apart from the seasonal variation induced by a drastic change in light and temperature in central Spain, the other factor controlling the levels of GEM was provided by the chosen mining method. For example, the June anomalous population from the El Entredicho (open pit mine) starts at a value 63 times higher than the anomalous one from Las Cuevas (underground mine), which suggests that largescale exposure of the ore, rather than the presence of waste dumps (they are present in both mines) accounts for most of the observed levels of atmospheric mercury. The rationale behind this idea is based on the following: as a sulfide ore body weathers, mercury is partly converted to the gaseous state (Carr et al., 1986); this phase disperses through the permeable rocks or cover, allowing gaseous mercury to be detected on the surface. However, sorption phenomena to oxide phases such as goethite $(\mathrm{FeOOH})$ may prevent the escape of mercury into the atmosphere (Carr et al., 1986). This would explain why the blind ore of Las Cuevas yielded a much smaller mercury signal than the exposed ore body of El Entredicho. However, having said this, we should make it clear that regional surveys have important shortcomings that are derived from their intrinsic nature. Thus, while they allow inspection of large areas, the characterization of specific areas may be flawed (underestimated GEM concentrations) or missed completely if the affected surface is not large enough to be detected.
For example, given that our regional studies were performed along roads, we did not enter the Las Cuevas installations and therefore the results may not reflect completely the nature of GEM emission at the site. That is the reason why we sequentially combined the regional and local scales to obtain a much clearer picture. We will return to the Las Cuevas case later in this paper.

The 2011 April survey was performed on the 28th of April, under clear skies and a mean temperature (10:00-17:00) of $20.9{ }^{\circ} \mathrm{C}$. Two LUMEX equipments were used, one for the Almadén area and the second for the rest of the district. The results indicated that most of the district had GEM concentrations equivalent to those of 2002. However, at Almadén a drastic change was observed involving a drop in GEM concentrations to about $35 \mathrm{ng} \mathrm{m}^{-3}$ (Table 1 ), thus reflecting the effectivity of main waste dump restoration works. We examine this case in the following section. A comparison with the results from the previous surveys shows that the 2011 anomalous population (whole district) starts at much lower concentrations: $31.62 \mathrm{ng} \mathrm{m}^{-3}$ (Fig. 2C) as compared to 39.81 and $1258.93 \mathrm{ng} \mathrm{m}^{-3}$ for the March 2002 and June 2002 surveys respectively (Fig. 2A and B). The analysis of data from the main source areas indicates an important decay in the anomalous population threshold for Almadén: $8.3 \mathrm{ng} \mathrm{m}^{-3}$ plus a transitional population between 8.3 and $24 \mathrm{ng} \mathrm{m}^{-3}$ for 2011 (Fig. 3C), against 316.23 and $630.98 \mathrm{ng} \mathrm{m}^{-3}$ for March and June 2002 respectively (Fig. 3A and B). Maxima and mean results (Table 1) confirm the important decay in GEM concentrations for the Almadén area. On the contrary, the storage and handling of liquid mercury at Las Cuevas in specially designed tanks resulted in an important increase in maxima and mean concentrations (2002 versus 2011 surveys) (Table 1). This is because in 2002 the mine was closed and the main atmospheric mercury source was 

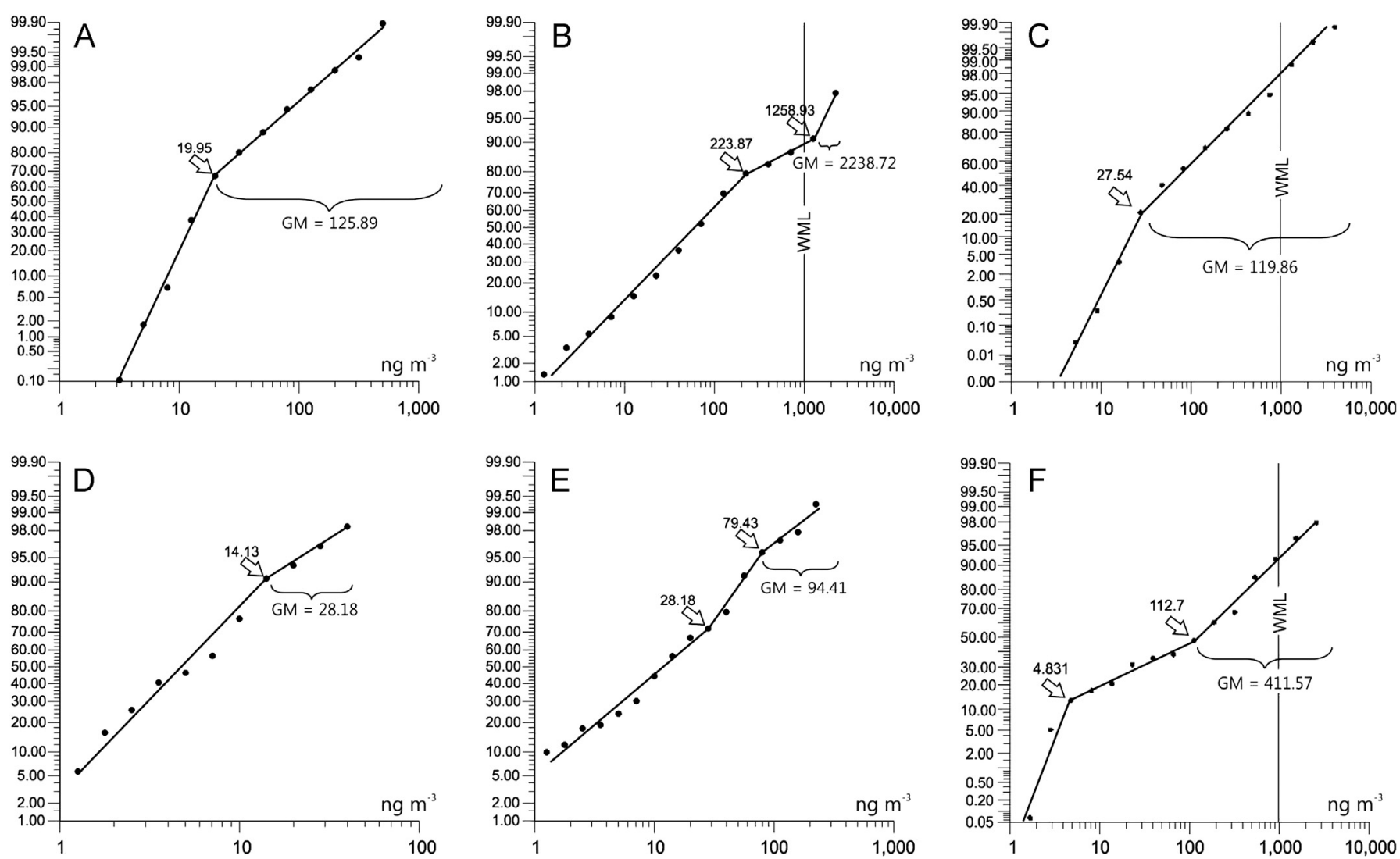

Fig. 4. Lepeltier graphics depicting distribution of normal and anomalous populations at (A-C) the inactive El Entredicho open pit mine and mineral dumps, during March 2002, June 2002 and April 2011; and (D-F) the Las Cuevas mine area during March 2002, June 2002 and April 2011. GM: geometric mean of the corresponding anomalous populations. WML: WHO (2000) maximum level.

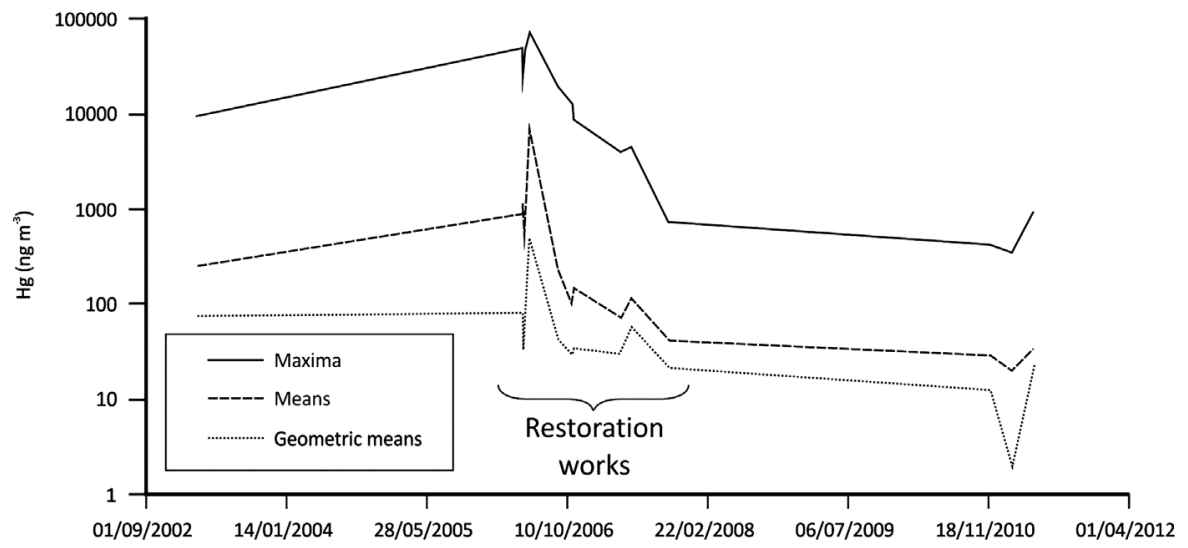

Fig. 5. Plot of means, geometric means and maxima mercury concentrations in the surroundings of the Almadén mine area, after the 15 local surveys carried out between March 2003 and April 2011.

the ore dump left in proximity to the mine until its reclamation in 2003. On the other hand, variations in GEM concentrations at Almadenejos and El Entredicho (Table 1) were of minor importance. This is curious considering the vast restoration works carried out at El Entredicho (restored waste dumps and flooding of the open pit) which apparently have not yielded the expected results regarding the lowering of mercury emissions.

\subsection{The Almadén site: effects of waste dump restoration works}

The restoration works carried out on the main waste dump of Almadén between 2006 and 2008 indeed lowered GEM emissions from the area. Our data are derived from 12 express surveys carried out in March 2003 (before restoration), between May and September 2006 (main restoration works involving slope modifications), and between September and October 2007 (while the dump was being covered with soil). Three additional surveys performed in 2010-2011 allowed inspection of the revegetated area. Although our express surveys were never identical, covering areas slightly different and under variable weather conditions, they nevertheless showed how GEM emissions increased during earth moving, and how these dropped to very low levels when the restoration works were completed (Figs. 5-7). Of particular interest for human health was the fact that for the first time since the industrial epoch, the post- 
restoration data indicated that GEM emission figures were well within safety conditions as defined by the ATSDR (1999) minimal risk level at $200 \mathrm{ng} \mathrm{m}^{-3}$, the USEPA (1997) reference for air concentration at $300 \mathrm{ng} \mathrm{m}^{-3}$, and even the WHO (2000) air quality guideline at $1000 \mathrm{ng} \mathrm{m}^{-3}$.

\subsection{The Las Cuevas site: modeling mercury emissions and Tekran data}

The modeling of mercury air emissions at Las Cuevas with the program ISC-AERMOD (Llanos et al., 2010) showed that whatever the many interactions between soils, mineral dumps and the handling of mercury vessels were, the main impact by GEM emissions was restricted to a relatively small area surrounding the Las Cuevas complex. When the program was loaded with GEM emission, meteorological (temperature, solar radiation, direction and speed of winds; rain precipitation and light hours) and soil use data, high concentrations of mercury (above $1000 \mathrm{ng} \mathrm{m}^{-3}$ ) were only predicted for a very short period of time $(1 \mathrm{~h})$. As the time factor increased to $24 \mathrm{~h}$ and up to a period of 11 months, there was a remarkable decrease in the plume size, which adopted a NW-SE elongated shape that was strongly controlled by the dominant winds. This comes out as a consequence of the progressive influence of winds in the model, which dilute the plume thus lowering the concentrations. As shown by Venkatram et al. (2004), although the AERMOD software accounts for wind properties, the PRIME algorithm neglects wind meandering (crucial in an area with variable topography such as Las Cuevas) and overestimates pollutant concentrations in the near-field modeling, that is, in the prediction of physical mixing processes involving mass advection and diffusion. If this is correct, then it is likely that long-term GEM contamination from Las Cuevas might be even less important than anticipated.

On the other hand, Tekran data for Las Cuevas (2007-2009) indicated GEM, RGM, and PM mean $2007-2009$ concentrations of $226.1,0.148$, and $0.386 \mathrm{ng} \mathrm{m}^{-3}$ respectively, that is, largely above those from background areas from North America and Europe, with levels of $1.6,0.04$, and $0.06 \mathrm{ng} \mathrm{m}^{-3}$ respectively (Table 2). Light and higher temperatures made GEM concentrations steadily increase from winter to spring. However, the summer vacation period (all works cease at Las Cuevas) results in a decrease in GEM levels (Table 3 and Fig. 8A). Other factors influencing GEM concentration include enhanced air flow and turbulence during daylight resulting in improved pollutant removal whereas the night brings stable stratification conditions suppressing the removal of this species. This results in GEM highs during night hours from 22:00 p.m. onwards. RGM and PM also undergo a remarkable increase from winter to spring although for different reasons. For example, an anthropic control over emissions was noted for PM, which increased during working hours from Monday to Friday due to traffic and mercury handling. On the other hand, RGM does not correlate with $\mathrm{O}_{3}$, therefore formation of this species could instead be related to the presence of halogen aerosols (e.g., Berg et al., 2003; Sigler et al., 2009). Thus, atmospheric mercury speciation at Las Cuevas comes as a consequence of combined natural and anthropic factors.

\subsection{The metallurgical precincts ("cercos") of Huerta del Rey and Almadenejos}

The Cerco Metalúrgico de Huerta del Rey (active before the 17 th century) is also an old mining and metallurgical area, located immediately to the north of the Almadén urban area (Fig. 1B). At present the only relicts of that activity are ruins, and the rest of the old calcine dumps. The results from 22 surveys in the area between February 2010 and January 2011 indicate that maxima GEM concentrations are up to $2500 \mathrm{ng} \mathrm{m}^{-3}$ during summer and below $500 \mathrm{ng} \mathrm{m}^{-3}$ during winter (Table 3 and Fig. 8B).

On the other hand, the Cerco Metalúrgico de Almadenejos (CDA) is adjacent to the small village of the same name (Fig. 1C). Despite being connected to Almadén (13 km) and other towns by

Table 2

Means and standard deviations of mercury species at Las Cuevas mine during 2007-2009. GEM: Gaseous elemental mercury; RGM: Reactive gaseous mercury; PM: Total particulated mercury. Data from background areas are from North America and Europe (AMAP/UNEP, 2008). All data in ng $\mathrm{m}^{-3}$.

\begin{tabular}{lcccc} 
& Winter & Fall & Spring & Summer \\
\hline GEM & $127.18 \pm 164.22$ & $242.23 \pm 215.98$ & $280.56 \pm 392.37$ & $223.72 \pm 281.05$ \\
RGM & $0.033 \pm 0.067$ & $0.084 \pm 0.282$ & $0.348 \pm 0.506$ & $0.080 \pm 0.057$ \\
PM & $0.228 \pm 0.451$ & $0.422 \pm 0.791$ & $0.526 \pm 1.017$ & 0.04 \\
\hline
\end{tabular}

Table 3

Seasonal variations in mercury concentrations at Las Cuevas mine (MLC), Cerco Metalúrgico de Almadenejos (CDA) and Cerco Metalúrgico Huerta del Rey (CMHR) sites. Data from the 37 LUMEX surveys carried out between April 2007 and January 2011. GM: Geometric mean. All data in $\mathrm{ng}^{-3}$.

\begin{tabular}{|c|c|c|c|c|c|c|c|c|c|c|c|c|c|}
\hline MLC & Season & Spr 2007 & Sum 2007 & Aut 2007 & Win 2007 & Spr 2008 & Sum 2008 & Aut 2008 & Win 2008 & Spr 2009 & Sum 2009 & Aut 2009 & Win 2009 \\
\hline & $\mathrm{N}$ & 1 & 10 & 2 & 3 & 2 & 3 & 2 & 2 & 2 & 4 & 3 & 1 \\
\hline & Mean & 74 & 101 & 55 & 130 & 111 & 107 & 74 & 86 & 70 & 206 & 90 & 43 \\
\hline & GM & 52 & 46 & 17 & 43 & 69 & 44 & 30 & 26 & 18 & 31 & 26 & 12 \\
\hline & Max & 274 & 2160 & 1074 & 2404 & 1708 & 6057 & 2742 & 2405 & 1068 & 9703 & 5194 & 456 \\
\hline \multirow[t]{5}{*}{ CDA } & Season & & & & Win 2008 & Spr 2009 & Sum 2009 & Aut 2009 & Win 2009 & Spr 2010 & Sum 2010 & Aut 2010 & Win 2010 \\
\hline & $\mathrm{N}$ & & & & 2 & 4 & 7 & 4 & 4 & 4 & 6 & 5 & 1 \\
\hline & Mean & & & & 128 & 82 & 146 & 70 & 35 & 99 & 168 & 117 & 35 \\
\hline & GM & & & & 32 & 20 & 28 & 18 & 14 & 20 & 25 & 22 & 8 \\
\hline & Max & & & & 2428 & 3117 & 4264 & 1456 & 690 & 2904 & 4996 & 3929 & 557 \\
\hline CMHR & Season & & & & & & & & Win 2009 & Spr 2010 & Sum 2010 & Aut 2010 & Win 2010 \\
\hline & $\mathrm{N}$ & & & & & & & & 2 & 4 & 6 & 6 & 4 \\
\hline & Mean & & & & & & & & 22 & 33 & 80 & 33 & 18 \\
\hline & GM & & & & & & & & 14 & 17 & 29 & 16 & 10 \\
\hline & Max & & & & & & & & 145 & 807 & 2594 & 1415 & 310 \\
\hline
\end{tabular}



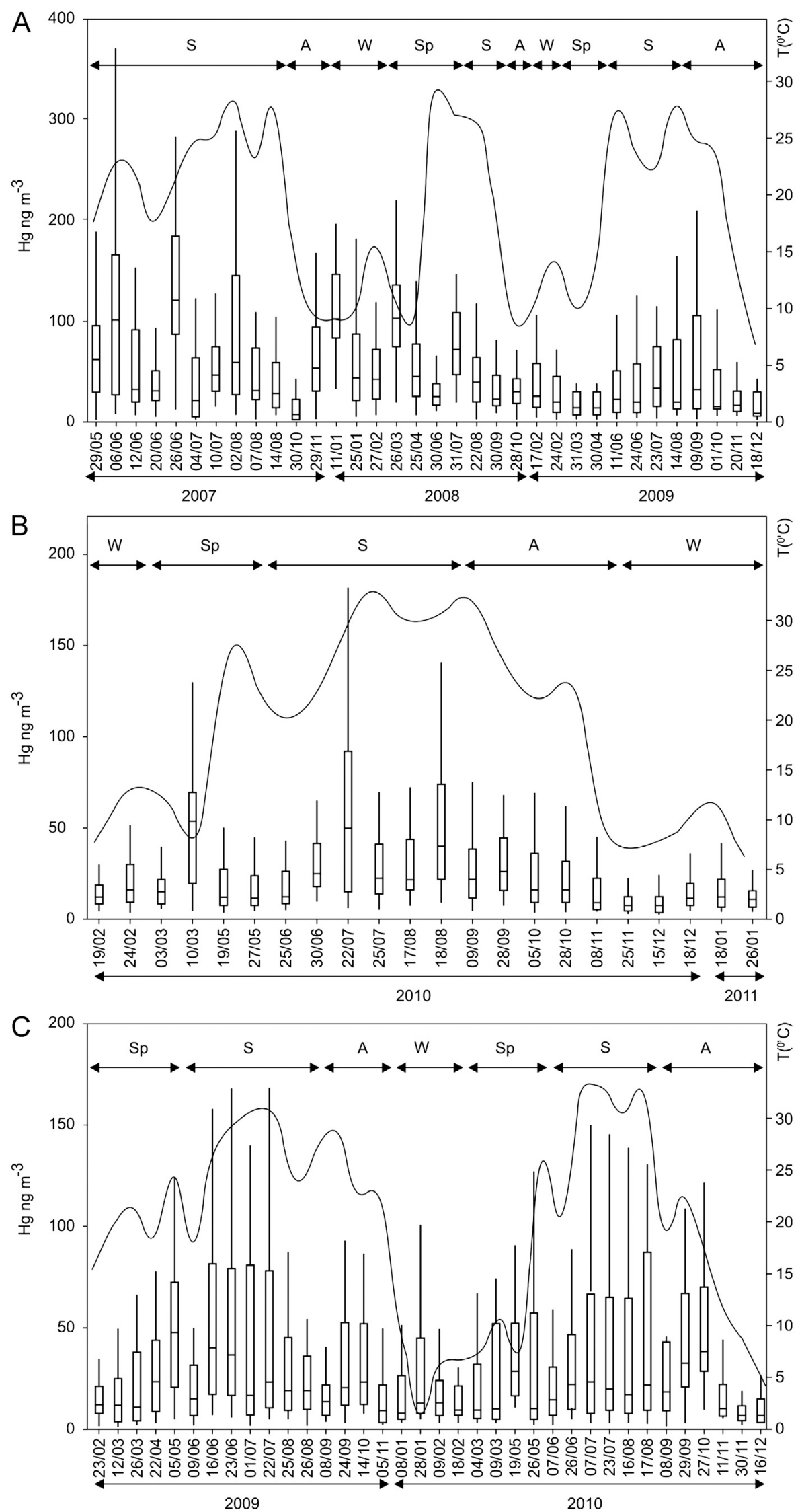

Fig. 6. Box-and-whisker plot of mercury concentrations and temperatures (left scale) during the 34 local surveys carried out between May 2005 and December 2009 in Las Cuevas mine area (A), the 22 surveys carried out between February 2010 and January 2011 in the Huerta del Rey decommissioned metallurgical precinct (B), and the 36 surveys carried out between February 2009 and December 2010 in the Almadenejos decommissioned metallurgical precinct (C). Sp: Spring; S: Summer; A: Autumn; W: Winter. 

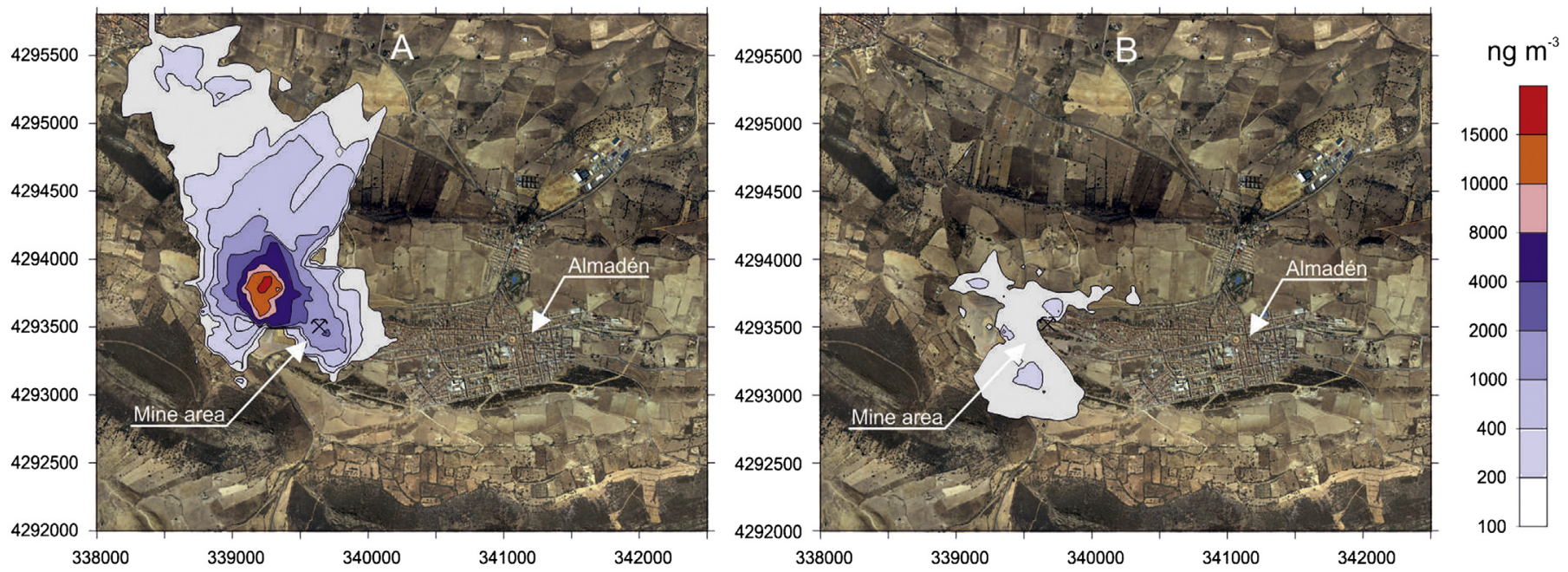

Fig. 7. GEM isocontents map in the Almadén mine area and surroundings, after the surveys carried out in May 2006 (A) and in October 2007 (B). Note that the main GEM source was the dump (located to the East of the mine area) in both cases. The shape of the GEM plume (to the north in A, to the south in B) depends on particular meteorological conditions, especially on wind speed and direction.
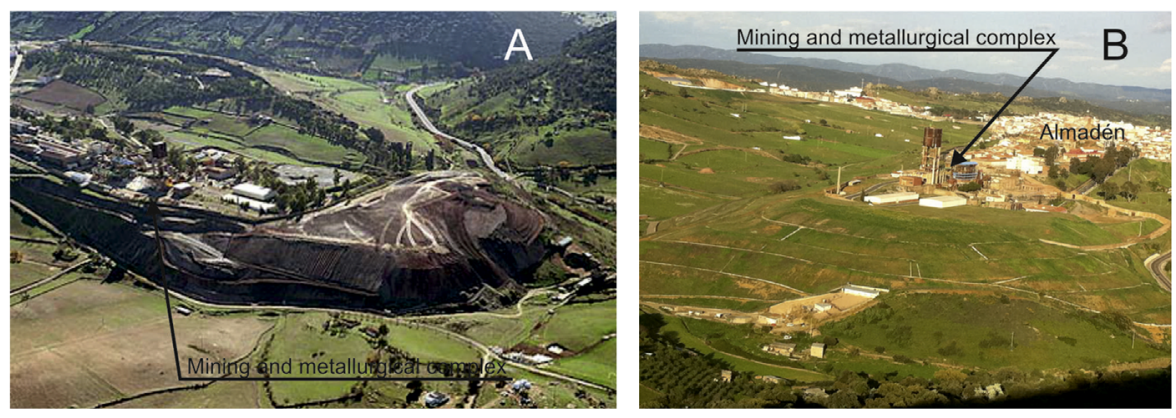

Fig. 8. The evolution of the Almadén mine main dump. A: before the dump reclamation started (2004); B: after the reclamation (May 2011). Note the proximity of the mine to the town area.

the regional road CR-424 there are plenty of reasons to say that Almadenejos is in the middle of nowhere, and as such, it has received little or no attention from an environmental point of view. The site is so unknown that only a few specialists on mercury in Spain could pinpoint its location on a map. This comes as a surprise, because after Almadén ceased to be the top environmental concern in the district, Almadenejos took the lead. At present, by far, and by any international standard, the CDA can be properly regarded as an environmental disaster area. The Bustamante furnaces that operated between 1795 and 1864 left polluted soils with concentrations of up to $15,900 \mu \mathrm{g} \mathrm{g}^{-1} \mathrm{Hg}$ (Martínez-Coronado et al., 2011). But the problem does not end here, because the soils induce strong GEM emissions. Llanos (unpublished) carried out 36 surveys between February 2009 and December 2010. The results indicate that GEM emissions are in turn controlled by seasonal variations, with maxima values reaching 4000-5,000 $\mathrm{ng} \mathrm{m}^{-3}$ during summer and minima concentrations below $1000 \mathrm{ng} \mathrm{m}^{-3}$ during winter (Table 3 and Fig. 8C).

\subsection{Assessing risks and solutions}

One of the main reasons for conducting environmental studies, particularly those on heavy metals, is the risk that these metals may pose to human health. In this regard the Almadén district leaves a number of good lessons concerning monitoring and assessment of potential and actual environmental risks. Soil $\mathrm{Hg}$ concentrations from 'non-contaminated areas' of the district are in the order of a few to tens of microgram per gram. One may say that these are ludicrous concentrations; however, compared to those from truly non-contaminated areas, in the range of 0.01-0.03 $\mu \mathrm{g} \mathrm{g}^{-1} \mathrm{Hg}$ (Senesi et al., 1999), these figures are huge. Thus, from a purely geochemical point of view, one may argue that the whole district is a large geochemical anomaly of mercury. However, having said this, the question is, do these $\mathrm{Hg}_{\text {soil }}$ levels pose a risk to the human population? From a historical perspective the answer is a categorical no, which is understandable given the low mobility and no bioavailability of the Almadén soils mercury species ( $>50 \%$ are cinnabar particles). There are no medical precedents indicating that the inhabitants (other than those working or living in strongly polluted sites) have ever developed a medical syndrome related to mercury inhalation or ingestion. Thus, we must carefully choose our words to assess the past and present environmental hazards. For example, we should be clear enough stating that GEM emissions in the order of 0 $40 \mathrm{ng} \mathrm{m}^{-3}$ (background population for March 2002 survey) do not pose any danger. However, and here comes the main issue, the statistical treatment of data from the following survey (June 2002) indicated that the GEM range of the background population was in the range of $0-1259 \mathrm{ng} \mathrm{m}^{-3}$. In this regard, the mere fact that we statistically call a population "background" does not imply that we are within safe environmental conditions, because 
part of the latter data fall within unacceptable levels as those indicated by the ATSDR (1999), USEPA (1997), and WHO (2000) safety standards. Thus, our first lesson concerns the statistical sense of "background", which although has a meaningful mathematical sense, can mislead (nevertheless) risk assessment (Figs. 7 and 8).

On the other hand, given that not "all" the measured concentrations of both $\mathrm{Hg}_{\text {soil }}$ and GEM can be attributed to industrial sources, part of the district 'background levels' must be derived from what we may call "natural contamination". This is the least one may expect from an area that was subjected to magmatic and metallogenic activity leading to intermittent mercury deposition during Silurian and Devonian time, i.e. a time-span of about 70 million years (Higueras et al., 2000). Nevertheless, these truly "background levels", in the range of a few or tens of microgram per gram for $\mathrm{Hg}_{\text {soil }}$ or nanograms per cubic meter for GEM, are not to be regarded as potential environmental risks at the district scale.

Although this natural contamination did (and does) not pose a risk in the district, that related to the mining and metallurgical processing of the mercury ore left a disastrous legacy that in a few cases persists until present time. Underground mining and metallurgical roasting resulted in large GEM emissions in the order of tens of thousands of nanograms per cubic meter. In fact, as explained by Menéndez Navarro (1994) for the 18th and 19th centuries, the extent and seriousness of the health problems suffered by workers at the mine (mainly hydragyrism) led to repeated labor shortages, a problem which reached its peak in the second half of the 18th century (Sánchez-Martín, 1924). Thus, the major environmental concerns of Almadén regarding human health were to be found in the industrial activities. After the ceasing of mining and metallurgical activities in 2003, the main remaining GEM source was the old waste dump, still emitting GEM well above international reference levels. The restoration works caused severe pollution incidents during the two years of earth moving; however, the works eventually resulted in a dramatic drop in GEM emissions, leaving the town below ATSDR (1999), USEPA (1997), and WHO (2000) maxima acceptable levels.

\subsection{What remains to be done and options for a sustainable future}

Given that GEM emissions at Almadén have been dropped to acceptable levels, at the district scale we are left with only one major persistent environmental concern: the Cerco de Almadenejos site, where summer emissions surpass even the most restrictive WHO (2000) guidelines at $1000 \mathrm{ng} \mathrm{m}^{-3}$. The problem of Almadenejos is aggravated because the local population lives adjacent to the old metallurgical precinct and livestock is freely raised within the ruins (Martínez-Coronado et al., 2011). In this regard, same as in the case of Almadén, the Cerco de Almadenejos requires immediate action regarding restoration. This could involve the removal of soils or their permanent capping to create an impermeable barrier. The latter procedure has many advantages (Evanko and Dzombak, 1997): (1) prevents water infiltration and therefore underground water contamination; (2) prevents gas emissions from the site; and last but not least, (3) eliminates risks associated with dermal contact and/or involuntary ingestion of contaminated soils, some of them containing highly toxic $\mathrm{Hg}$ species (Gray et al., 2004) with proven human toxicity (Gray et al., 2010).

Thus, restoration is the keyword here and brings us to the second and most important lesson: even truly disastrous areas such as the Almadén mining and metallurgical complex can be dealt with if money is invested in the "future" and land reclamation is done. We may not entirely agree with the procedures used to restore the old waste dump, but we do recognize that the works have returned Almadén to almost pre-industrial times, at least for the time being and where GEM emissions are concerned.
Additionally, the restoration works at Almadén were part of a more ambitious plan involving conversion of the mine and metallurgical plant into an educational park for visitors.

Mining can aspire to compatibility with sustainable development if the exploitation of a mineral deposit gives rise to longterm benefits of the environmental and/or social and/or economic type, which in turn should equal or exceed the values that existed prior to exploitation (Amezaga et al., 2011). In this regard, we believe that MAYASA (the mining company) has set up the foundations for sustainability in an economically depressed area, by improving environmental conditions, providing jobs to old exminers in the educational park that otherwise would be on the doll, and creating economic expectatives for the town via educational tourism.

\section{Conclusions}

As shown by the studied case, years of almost constant monitoring provide a unique vision of contaminated sites. We have seen how in less than one decade GEM levels have fallen drastically in one of the most polluted sites of the world: the Almadén mining-metallurgical complex. The site is now under acceptable conditions for GEM emissions by any of the most important international reference safety standards (ATSDR, USEPA, WHO). It was first the ceasing of mining and metallurgical practices in 2003 and then the finalization of restoration works in the main waste dump (2008) that allowed return in GEM emissions to almost pre-industrial conditions. However, there is still work to be done in the district, and the old metallurgical precinct of Almadenejos should be the next step. GEM levels of up to 4000-5000 $\mathrm{ng} \mathrm{m}^{-3}$ at the site are totally unacceptable by any local or international standard.

\section{Acknowledgments}

This study has been partly funded by the European LIFEEnvironment programme through project MERSADE (LIFE06 ENV/ ES/PREP/03), as well as by the Spanish Ministry of "Economía y Competitividad" through Project CGL2009-13171-C03-01, and by Castilla-La Mancha Regional Government "Consejería de Educación” Project PII1I09-0142-4389.

\section{References}

Abbott, M.L., Lin, C.-J., Martian, P., Einerson, J.J., 2008. Atmospheric mercury near Salmon falls creek reservoir in southern Idaho. Appl. Geochem. 23, 438-453.

Amezaga, J., Rötting, T., Younger, P., Nairn, R.W., Noles, A.J., Oyarzún, R., Quintanilla, J., 2011. A rich vein? Mining and the pursuit of sustainability. Environ. Sci. Technol. 45, 21-26.

AMAP/UNEP, 2008. Technical Background Report to the Global Atmospheric Mercury Assessment. Arctic Monitoring and Assessment Program/UNEP Chemical Branch, 〈http://www.unep.org/hazardoussubstances/Mercury/Mercury Publications/GlobalAtmosphericMercuryAssessmentSourcesEm/tabid/3618/ Default.aspx $>159 \mathrm{pp}$.

ATSDR, 1999. Toxicological Profile for Mercury. Agency for Toxic Substances and Disease Registry, U.S., 〈http://www.atsdr.cdc.gov/toxprofiles/tp46.html 〉, (accessed 04.12).

Berg, T., Sekkesæter, S., Steinnes, E., Valdal, A.K., Wibetoe, G., 2003. Springtime depletion of mercury in the European Arctic as observed at Svalbard. Sci. Total Environ. 304, 43-51.

Billings, Ch., Matson, W.R., 1972. Mercury emissions from coal combustion. Science 176, 1232-1233.

Carr, G.R., Wilmshurst, J.R., Ryall, W.R., 1986. Evaluation of mercury pathfinder techniques: base metal and uranium deposits. J. Geochem. Explor. 26, 1-117.

Castillo Cuacés, W.O. (2012). Mercurio En Suelos Del Sector De La Mina La Nueva Concepción, Distrito Minero de Almadén (España). M.Sc. Thesis, Universidad Complutense, unpublished $45 \mathrm{pp}$.

Esbrí, J.M., Bernaus, A., Avila, M., Kocman, D., García-Noguero, E.M., Guerrero, B., Gaona, X., Alvarez, R., Perez-Gonzalez, G., Valiente, M., Higueras, P., Horvat, M., 
Loredo, G., 2010. XANES speciation of mercury in three mining districtsAlmadén, Asturias (Spain), Idria (Slovenia). J. Synchrotron. Radiat. 17, 179-186.

EUR-Lex, 2005. Access to European Union Law. Communication from the Commission to the Council and the European Parliament-Community Strategy Concerning Mercury [SEC (2005) 101], 〈http://eur-lex.europa.eu/LexUriServ LexUriServ.do?uri=CELEX:52005DC0020:EN:NOT $\rangle$.

European Union, 2006. LIFE News. LIFE Unit, Directorate General Environment, European Commission, No. 11/06, 〈http://81.188.27.167/environment/life/ news/lifeflash/lifenews11_06.htm, April 2012 >.

Evanko, C.R., Dzombak, D.A., 1997. Remediation of Metals-Contaminated Soils and Groundwater. Ground-Water Remediation Technologies Analysis Center Pittsburgh, 〈http://www.cluin.org/download/toolkit/metals.pdf $\rangle$, (accessed 04.12) $61 \mathrm{pp}$.

Fernández-Patier, R., Ramos-Díaz, M.C., 2011. Informe del Ejercicio de lntercomparación de Mercurio Gaseoso total en aire ambiente "IN SITU" (año 2011) Ined. Repport, Instituto de Salud Carlos III, Centro Nacional de Sanidad Ambiental, Área de Contaminación Atmosférica. Ministerio de Economía y Competitividad, España, 7 pp.

Ferrara, R., Maserti, B.E., Andersson, M., Edner, H., Ragnarson, P., Svanberg, S. Hernandez, A., 1998. Atmospheric mercury concentrations and fluxes in the Almaden district (Spain). Atmos. Environ. 32, 3897-3904.

Gray, J.E., Hines, M.E., Higueras, P.L., Adatto, I., Lasorsa, B.K., 2004. Mercury speciation and microbial transformations in mine wastes, stream sediments, and surface waters at the Almadén mining district, Spain. Environ. Sci. Technol. 38, 4285-4292.

Gray, J.E., Plumlee, G.S., Morman, S.A., Higueras, P.L., Crock, J.G., Lowers, H.A., Witten, M.L., 2010. In vitro studies evaluating leaching of mercury from mine waste calcine using simulated human body fluids. Environ. Sci. Technol. 44, $4782-4788$

Gustin, M.S., Lindberg, S.E., Austin, K., Coolbaugh, M., Vette, A., Zhang, H., 2000 Assessing the contribution of natural sources to regional atmospheric mercury budgets. Sci. Total Environ. 259, 61-71.

Gustin, M.S., Biester, H., Kim, C.S., 2002. Investigation of the light-enhanced emission of mercury from naturally enriched substrates. Atmos. Environ. 36 3241-3254

Gustin, M.S., Lindberg, S.E., Weisberg, P.J., 2008. An update on the natural sources and sinks of atmospheric mercury. Appl. Geochem. 23, 482-493.

Hall, B.D., Olson, M.L., Rutter, A.P., Frontiera, R.R., Krabbenhoft, D.P., Gross, D.S. Yuen, M., Schauer, J.J., 2006. Atmospheric mercury speciation in Yellowstone National Park. Sci. Total Environ. 367, 354-366.

Herrera Jimenez, E.A. 2012. Mercurio en aire y líquenes (Evernia prunastri) en el sector de la mina La Nueva Concepción, distrito minero de Almadén (España). M.Sc. Thesis, Universidad Complutense, unpublished $43 \mathrm{pp}$.

Higueras, P., Oyarzun, R., Munhá, J., Morata, D., 2000. Palaeozoic magmatic-related hydrothermal activity in the Almadén syncline (Spain): a long-lasting Silurian to Devonian process? Trans. Inst. Min. Metall. (Sect. B: Appl. Earth Sci.) 109 199-202.

Higueras, P., Oyarzun, R., Biester, H., Lillo, J., Lorenzo, S., 2003. A first insight into mercury distribution and speciation in soils from the Almadén mining district, Spain. J. Geochem. Explor. 80, 95-104.

Higueras, P., Oyarzun, R., Lillo, J., Sánchez-Hernández, J.C., Molina, J.A., Esbrí, J.M., Lorenzo, S., 2006. The Almadén district (Spain): Anatomy of one of the world's largest Hg-contaminated sites. Sci. Total Environ. 356, 112-124.

ISO/IEC Guide 43-1, 1997. Proficiency Testing by Interlaboratory Comparisons Part 1: Development and Operation of Laboratory Proficiency Testing. 〈http://www. iso.org/iso/iso_catalogue/catalogue_tc/catalogue_detail.htm? csnumber=27216 $\rangle$ (accessed 04.12).

Kocman, D., Horvat, M., 2011. Non-point source mercury emission from the Idrija Hg-mine region: GIS mercury emission model. J. Environ. Managem. 92, 2038-2046.

Landis, M.S., Keeler, G.J., 2002. Atmospheric mercury deposition to lake Michigan during the lake Michigan mass balance study. Environ. Sci. Technol. 36 4518-4524.

Lee, K.J. Lee, T.G., 2012. A review of international trends in mercury management and available options for permanent or long-term mercury storage. Journal of Hazardous Materials 241-242, 1-13.

Lepeltier, C., 1969. A simplified statistical treatment of geochemical data by graphical representation. Econ. Geol. 64, 538-550.

Limpert, E., Stahel, W.A., Abbot, M., 2001. Log-normal distributions across the sciences: keys and clues. Bioscience 51, 341-352.
Llanos, W., Higueras, P., Oyarzun, R., Esbrí, J.M., López-Berdonces, M.A., GarcíaNoguero, E.M., Martínez-Coronado, A., 2010. The MERSADE (European union) project: Testing procedures and environmental impact for the safe storage of liquid mercury in the Almadén district, Spain. Sci. Total Environ. 408, 4901-4905

Llanos, W. Modelización De Las Emisiones De Mercurio Gaseoso A La Atmosfera En El Distrito Minero De Almadén (Provincia de Ciudad Real). Ph.D. Thesis, Universidad Complutense, Madrid, Spain, unpublished $264 \mathrm{pp}$.

Llanos, W., Kocman, D., Higueras, P., Horvat, M., 2011. Mercury emission and dispersion models from soils contaminated by cinnabar mining and metallurgy. J. Environ. Monitor. 13, 3460-3468.

Lyman, S.N., Gustin, M.S., 2008. Speciation of atmospheric mercury at two sites in northern Nevada, USA. Atmos. Environ. 42, 927-939.

Martínez-Coronado, A., Oyarzun, R., Esbrí, J.M., Llanos, W., Higueras, P., 2011. Sampling high to extremely high Hg concentrations at the Cerco de Almadenejos, Almadén mining district (Spain): The old metallurgical precinct (1794 to 1861 AD) and surrounding areas. J. Geochem. Explor. 109, 70-77.

Menéndez Navarro, A., 1994. Medical attention for the miners of Almadén in the 18 th and 19th century. Quad. Int. Stor. Med. Sanita 3, 51-69.

Pacyna, J.M., Munch, J., 1991. Anthropogenic mercury emission in Europe. Water Air Soil Pollut. 56, 51-61.

Pacyna, E.G., Pacyna, J.M., 2002. Global emission of mercury from anthropogenic sources in 1995. Water Air Soil Pollut. 137, 149-165.

Pacyna, E.G., Pacyna, J.M., Steenhuisen, F., Wilson, S., 2006. Global anthropogenic mercury emission inventory for 2000. Atmos. Environ. 40, 4048-4063.

Pacyna, E.G., Pacyna, J.M., Sundseth, K., Munthe, J., Kindbom, K., Wilson, S. Steenhuisen, F., Maxson, P., 2010. Global emission of mercury to the atmosphere from anthropogenic sources in 2005 and projections to 2020. Atmos. Environ. 44, 2487-2499.

Peterson, C., Gustin, M., 2008. Mercury in the air, water and biota at the Great Salt Lake (Utah, USA). Sci. Total Environ. 405, 255-268.

Pirrone, N., Cinnirella, S., Feng, X., Finkelman, R.B., Friedli, H.R., Leaner, J., Mason, R., Mukherjee, A.B., Stracher, G.B., Streets, D.G., Telmer, K., 2010. Global mercury emissions to the atmosphere from anthropogenic and natural sources. Atmos. Chem. Phys. 10, 5951-5964.

Poissant, L., Pilote, M., Beauvais, C., Constant, P., Zhang H.H., 2005. A year of continuous measurements of three atmospheric mercury species (GEM, RGM and Hgp) in southern Québec, Canada. Atmos. Environ. 39, 1275-1287.

Sánchez-Martín, G., 1924. Estudio médico del hidrargirismo en las Minas de Almadén. Revista Minera, Madrid 89 p.

Senesi, G.S., Baldassare, G., Senesi, N., Radina, B., 1999. Trace element inputs into soils by anthropogenic activities and implications for human health. Chemosphere 39, 343-377.

Sholupov, S., Pogarev, S., Ryzhov, V., Mashyanov, N., Stroganov, A., 2004. Zeeman atomic absorption spectrometer RA-915 + for direct determination of mercury in air and complex matrix samples. Fuel Process. Technol. 85, 473-485.

Sigler, J.M., Mao, H., Talbot, R., 2009. Gaseous elemental and reactive mercury in Southern New Hampshire. Atmos. Chem. Phys. 9, 1929-1942.

Slemr, F., 1996. Trends in atmospheric mercury concentrations over the Atlantic ocean and at wank summit, and the resulting constraints on the budget of atmospheric mercury. In: Baeyens, W., Ebinghaus, R., Vasiliev, O. (Eds.), Global and Regional Mercury Cycles: Sources, Fluxes and Mass Balances, 21. Kluwer Academic Publishers, Netherlands, pp. 33-84.

Tekran, 2012. Tekran 2537 CVAFS Automated Ambient Air Analyzer. Tekran Products-Ambient Air, 〈http://www.tekran.com/products/ambient-air/tek ran-model-2537-cvafs-automated-mercury-analyzer/ $>$ (accessed 04.12).

USEPA, 1997. Mercury study report to Congress (Volume V: Health effects of mercury and mercury compounds). EPA-452/R-97-007V. United States Environmental Protection Agency, Washington DC, USA, www.epa.gov/hg/ report.htm. (Accessed 04 12) 349 pp.

Venkatram, A., Isakov, V., Yuan, J., Pankratz, D., 2004. Modeling dispersion a distances of meters from urban sources. Atmos. Environ. 38, 4633-4641.

Wängberg, I., Munthe, J., Pirrone, N., Iverfeld, Å., Bahlman, E., Costa, P., Ebinghaus, R., Feng, X., Ferrara, R., Gårdfeldt, K., Kock, H., Lanzillotta, E., Mamane, Y., Mas, F., Melamed, E., Osnat, Y., Prestbo, E., Sommar, J., Schmolke, S., Spain, G., Sprovieri, F., Tuncel, G., 2001. Atmospheric mercury distribution in northern Europe and in the Mediterranean region. Atmos. Environ. 35, 3019-3025.

WHO, 2000. Air Quality Guidelines for Europe. WHO Regional Publications European Series 91, World Health Organization Regional Office for Europe, Copenhagen, 288 pp. 